\title{
Experimental Research of Dry Friction in "Alumina Ceramics - Quartz Glass" Pair
}

Ivan Abramov ${ }^{1}$, Pavol Božek ${ }^{2}$, Pavel Lekomtsev ${ }^{1}$, Yury Nikitin ${ }^{1}$, Aleksey Shchenyatsky ${ }^{1}$

${ }^{1}$ Departament of Mechatronic Systems, Kalashnikov Izhevsk State Technical University, ul. Studencheskaya 7, 426069 Izhevsk, Russia..E-mail: abramov@istu.ru, lekomtsev@istu.ru, nikitin@istu.ru,bkkupol@istu.ru

${ }^{2}$ Institute of Applied Informatics, Automation and Mathematics, Faculty of Materials Science and Technology, Slovak University of Technology, Hajdóczyho 1, 91724 Trnava, Slovakia. E-mail: pavol.bozek@stuba.sk

Results of an experimental research of friction coefficient in "alumina ceramics - quartz glass" friction pair are presented. The research with pin on disc test configuration using SRV-III test machine was carried out at loads from 10 to $1000 \mathrm{~N}$, constant sliding velocities $5 \mathrm{~mm} / \mathrm{s}$; ambient temperature $23^{\circ} \mathrm{C}$ and relative humidity $30 \%$. The obtained results reveal that in general, friction coefficient for "alumina ceramics - quartz glass" pair decreases with the increase in normal load. It is shown that the obtained friction coefficients values at the normal force from 100 to $1000 \mathrm{~N}$ for the given experimental conditions can be used to pre-estimate the interference fits in "alumina ceramics - quartz glass" friction pairs.

Keywords: Friction coefficient, Friction force, Alumina ceramics, Quartz glass, Normal load.

\section{Acknowledgement}

The reported study was funded by RFBR according to the research project No. 16-38-00719 "Investigation of brittle contact interaction interface of non-metallic interference fit parts".

The contribution is sponsored by project KEGA MŠ SR No 006STU-4/2015 prepared project „University textbook "The means of automated production" by interactive multimedia format for STU Bratislava and Košice". This publication is the result of implementation of the project: "UNIVERSITY SCIENTIFIC PARK: CAMPUS MTF STU - CAMBO" (ITMS: 26220220179) supported by the Research \& Development Operational Program funded by the EFRR.

\section{References}

[1] CZICHOS, H., HABIG, K. H. (2010). Tribologie-Handbuch. Tribometrie, Tribomaterialien, Tribotechnik. Springer Vieweg, Wiesbaden.

[2] STRAFFELINI, G. (2015). Friction and Wear Methodologies for Design and Control, Springer, Switzerland.

[3] SWAIN, M. V. (1979). Microfracture About Scratches in Brittle Solids / In: Proceedings of The Royal Society A (Proc Math Phys Eng Sci), Vol. 366, Issue 1727, pp. 575-597.

[4] ZUM GAHR, K. H. (1987). Microstructure and Wear of Materials, Tribology, series no 10, Elsevier, Amsterdam.

[5] PIVARČIOVÁ, E., BOŽEK, P. (2014). Industrial production surety factor increasing by a system of fingerprint verification. In ISEEE 2014 : proceedings. International conference on Information Science, Electronics and Electrical Engineering. April 26-28, 2014, Sapporo City, Hokkaido, Japan. Beijing: IEEE, 2014.

[6] POPOV, V. L. (2010). Kontaktmechanik und Reibung. Von der Nanotribologie bis zur Erdbebendynamik. Springer-Verlag Berlin Heidelberg.

[7] ABRAMOV, A., ABRAMOV, I., LEKOMTSEV, P. (2013). Analyzing the Accuracy of Conical Holes, Obtained by Method of Elastic-Plastic Deformation in Fluid Friction Mode. In: Bulletin of Kalashnikov ISTU, Vol. 60, No. 4, pp. 28 - 30. Kalashnikov Izhevsk State Technical University Press, Izhevsk.

[8] SCHINDOWSKI, E., SCHÜRZ, O. (1974). Statistische Qualitätskontrolle: Kontrollkarten und Stichprobenpläne. Verlag Technik, Berlin.

[9] KRAGELSKY, I. V. (1968). Friction and Wear. 2nd ed., revised and enlarged. Mashinostroenie, Moscow.

[10] Ceramic and Glass Materials: Structure, Properties and Processing. (2008). Editors: James F. Shackelford, Robert H. Doremus. Springer. New York.

[11] WACHTMAN, J. B., CANNON, W. R., MATTHEWSON, M. J. (2009). Mechanical Properties of Ceramics, 2nd Edition., John Wiley \& Sons.

[12] FABIAN, M., STANOVÁ, E., FEDORKO, G., KMEŤ, S., FABIANOVÁ, J., KRAJŇÁK, J. (2016). Parametric CAD model of a double-lay six strand wire rope. In Manufacturing Technology. Volume 16, Issue 3, 2016, Pages 489-496. 
[13] ABRAMOV, I. V., LEKOMTSEV, P. V., TREFILOV, N. A. (2015). Computer research of load-carrying capacity for tapered interference fit made of brittle nonmetallic parts. In: Intelligent Systems in Manufacturing, Vol. 26, No. 2, pp. 44 - 51. Kalashnikov Izhevsk State Technical University Press, Izhevsk.

[14] ABRAMOV, I., TURYGIN, Y., LEKOMTSEV, P., ROMANOV, A. (2016). Friction Coefficients in Tapered Interference Fits of Parts Made of Hard Brittle Materials. In: Intelligent Systems in Manufacturing, Vol. 31, No. 4, pp. 45 - 47. Kalashnikov Izhevsk State Technical University Press, Izhevsk.

[15] NOVAK, M. (2012). Surfaces with high precision of roughness after grinding. In Manufacturing Technology. Volume 12, Issue 1, 2012, Pages 66-70.

[16] PEŠKOVÁ, A., DEMEČ, P. (2016). Cost Modeling for ABC Failure of Machines In Manufacturing Technology. Volume 17, 2016, Pages 76-79.

[17] HOLESOVSKY, F., NAPRSTKOVA, N., NOVAK, M. (2012). GICS for grinding process optimization In Manufacturing Technology. Volume 12, Issue 1, 2012, Pages 22-26.

[18] KURYŁO, P., FRANKOVSKÝ, P., TERTEL, E., JANEK, J. (2015). The use of mathematical model of hardness spread in the research on the property of cast-iron molds. Metalurgija, 54(1), pp. 105-108.

[19] STRAKA, M., KAČMÁRY, P., ROSOVÁ, A., YAKIMOVICH, B., KORSHUNOV, A. (2016). Model of unique material flow in context with layout of manufacturing facilities. In Manufacturing Technology. Volume 16, Issue 4, 2016, Pages 814-820.

[20] BOŽEK, P., POKORNÝ, P. (2014). Analysis and evaluation of differences dimensional products of production system. In Applied Mechanics and Materials. Vol. 611 (2014), s. 339-345. ISSN 1660-9336.

[21] KORSHUNOV, A. (2007). The generalized model of valuation of constructive-technological complexity of a machine-building item. In Pollack Periodica, Volume 2, Issue 3, December 2007, Pages 135-146.

[22] DOMBRACHEV, A., YAKIMOVICH, B., KORSHUNOV, A., KRUTIKHIN, A. (2015). Effectiveness of the Lineika CAD system in assessing the precision of time standards. In Russian Engineering Research Volume 35, Issue 5, 18 May 2015, Pages 369-371.

[23] OSTERTAGOVÁ, E., FRANKOVSKÝ, P., OSTERTAG, O. (2016). Application of polynomial regression models for prediction of stress state in structural elements. Global Journal of Pure and Applied Mathematics, 12.4, pp. 3187-3199. 